\title{
Black Immigrants in Portugal: Luso-Tropicalism and Prejudice
}

\author{
Jorge Vala* \\ University of Lisbon
}

\section{Diniz Lopes}

ISCTE, Lisbon

\section{Marcus Lima}

Federal University of Sergipe

This article analyzes the relationship between the luso-tropicalist representation of the history of Portuguese colonization and overt as well as covert expressions of anti-immigrant prejudice. The luso-tropicalist representation emphasizes the uniqueness of the Portuguese colonial relations based on Portuguese empathy and capacity to deal with people from different cultures. This representation was created during Salazar's dictatorial regime and is still assumed to be a dimension of Portuguese national identity. The empirical findings presented in this article show that this luso-tropicalist representation may explain the salience of the norm against prejudice in Portugal and may contribute to weaken the traditional association between national identity and overt prejudice. A second dimension of the association between luso-tropicalism and integration of Black immigrants in Portuguese society was examined, that is, the impact of luso-tropicalism on the attribution and covert evaluation of cultural differences between White Portuguese and Black immigrants. Results show that despite the luso-tropicalist representation, White Portuguese individuals express a covert negative evaluation of cultural differences attributed to Black immigrants. This means that the luso-tropicalist representation can protect against the expression of overt prejudice but not against its covert dimensions.

* Correspondence concerning this article should be addressed to Jorge Vala, Instituto de Ciências Sociais da Universidade de Lisboa, Av. Prof. Aníbal de Bettencourt, 9, 1600-189 Lisboa [e-mail: jorge.vala@ics.ul.pt]. 
For many years, Portugal was a country of emigrants. In the last decades, and especially in the last 10 years, Portugal became a country of immigration receiving immigrants from the former Portuguese colonies in Africa, from Brazil, and from Eastern Europe. Official statistics show that $5 \%$ of the people living in Portugal are legal immigrants, most of them coming from the Portuguese ex-colonies. In this context, how does the Portuguese society react to immigration, specifically to immigrants who have an African origin?

This issue of the Journal of Social Issues is dedicated to the analysis of prejudice in Europe. Hence, we analyze the psychological dynamics of racial and anti-immigrant prejudice in Portugal within the context of a specific representation of the history of Portuguese colonial relations: the luso-tropicalist representation. Luso-tropicalism as a social representation emphasizes the uniqueness of Portuguese colonial relations based on the Portuguese capacity to deal with people from different cultures.

Luso-tropicalism is a theory proposed by the anthropologist Gilberto Freyre in 1933 to explain the construction of Brazilian identity. It was selectively appropriated by Salazar's dictatorial regime (1926-1974) in order to legitimize Portuguese colonialism, accentuating the absence of racism in the Portuguese colonies as well as Portuguese empathy toward other people, specifically Black people (Castelo, 1999; Freyre, 1933; Valentim, 2003). Today, luso-tropicalism is still considered a part of Portuguese national identity. This article is framed within the general hypothesis that representations of a nation concerning its history and its colonial past may contribute to understanding today's reactions toward immigrants and immigration in Portugal.

In a study of racism in Portugal, Vala, Brito, and Lopes (1999) showed that antiBlack prejudice could be described using Pettigrew and Meerten's (1995) distinction between blatant and subtle prejudice-a distinction found using Eurobarometer-30/1988 data-samples from the United Kingdom, Belgium, France, Holland, and Germany. In Vala et al.'s (1999) study, it was also shown that antiBlack prejudice in Portugal had the same predictors as those found by Pettigrew and Meertens. Nevertheless, there was a critical exception in the Portuguese sample: anti-Black prejudice was not predicted by national identity, as it was the case in the countries studied by Pettigrew and Meertens. How can this result be explained?

In an exploratory way, we propose that the absence of an association between national identity and prejudice, and the salience of an antiprejudice norm in Portugal can be explained within the framework of the luso-tropicalist representation. In the second part of this article we show that the luso-tropicalist representation does not affect covert forms of prejudice based on the attribution of cultural differences, as much as it affects open expression of blatant prejudice. 


\section{Luso-Tropicalism, Prejudice, and National Identification}

Luso-tropicalism is based on the hypothetical existence of a specific Portuguese cultural trait: the natural capacity and ability of Portuguese to relate to people that are seen as different-a trait that would explain the unique character of colonial relationships and that would, nowadays, have a positive impact on the relationships between Portuguese and immigrants.

This hypothetical dimension of the Portuguese "national character" was created and spread by the anthropologist Gilberto Freyre in his famous book Casa Grande e Senzala (Masters and Slaves, 1933), a book in which he proposed the concept of luso-tropicalism ${ }^{1}$ to explain the apparent success of relations between different cultures in Brazil, as well as the cultural and biological mestiçagem ${ }^{2}$ that occurred in this same country. This anthropological theory was subjected to a selective interpretation by the ideology of Salazar's dictatorial regime (Alexandre, 1999) and was transformed into a social representation (Moscovici, 1984).

Shielded by this representation, the Portuguese colonization is seen as more humane than the Spanish or English colonization. English colonial systems were characterized by a social distance between the colonizers and the colonized; Spanish colonization practices included the extermination of the colonized, well described by De Las Casas (1552/1996). These characteristics find no equivalent in the Portuguese colonization process according to the luso-tropicalist representation. In G. Freyre's words, a Portuguese "would be Spanish without the war flame or the dramatic orthodoxy; and would be English without the puritan rules. He would be the 'non-conflictual' type—not with absolute ideas, nor inflexible prejudices" (Freyre, 1933, p. 191). In the past, these Portuguese characteristics would have generated harmonious relations between colonizers and colonized in Brazil. In the present these same characteristics may have generated "the Brazilian racial democracy" (for a discussion see Alexandre, 1999; Castelo, 1999; Valentim, 2003), and in Portugal a more positive attitude toward immigrants, namely Black immigrants, as compared to other European countries. A study carried out with Portuguese university students concerning the support of three of the main components of the luso-tropicalist representation showed that participants actually believe that the Portuguese colonization process was more benevolent, that

\footnotetext{
${ }^{1}$ The word luso comes from the Latin word lusus to designate the Portuguese. Luso-tropicalism generally refers to the relationship between the Portuguese and natives of "tropical countries."

${ }^{2}$ Mestiçagem, as in miscegenation, refers to a process of crossing "races" or individuals of different "races," specifically White Portuguese and Black Africans. According to Gilberto Freyre, in Brazil the process of mestiçagem was based, among other reasons, on the fact that Portugal was itself a product of a process of mestiçagem: "Portugal is a good example of a European country of 'transitory blonds' or of "half-blonds." In the regions where there is greater dissemination of Nordic blood, children are born blond and with "pink" skin, like a Flemish baby Jesus, and become dark skinned and dark haired when they reach adulthood. . . these 'double-colored hair mestizos' generated, in our view, the majority of the Portuguese colonizers of Brazil”' (p. 204).
} 
it originated more mestiçagem, and that, nowadays, racism is expressed less frequently in Portugal than in other European countries (Valentim, 2003).

From an objective point of view, it is hard to believe that the relations between Portuguese and colonized people were cordial. It will suffice to remember that De Las Casas wrote not only about the extermination of Indians by Spanish colonizers, but also about the extermination of Black people by the Portuguese (De Las Casas, 1552/1996). It should also be noted that between 3 million and 18 million Africans were made slaves and transported to Brazil, and that the Portuguese colonization in this last country led to the death of 5 million native Indians (Munanga, 1996; Schwarcz, 1996).

\section{Luso-Tropicalism and the Antiprejudice Norm}

Despite this somber history, luso-tropicalism functions as a representation of the uniqueness and kindness of the Portuguese colonization, and of the relations between Portuguese and other people. And it helps to explain the prevalence of an antiprejudice norm in Portugal. In fact, Vala et al. (1999), using Pettigrew and Meertens's scales, showed that the expression of anti-Black subtle prejudice is much higher than the expression of blatant prejudice: while $44.7 \%$ of the respondents express subtle prejudice, only $16 \%$ of the participants answered in a way that violated the norm of antiblatant prejudice against Black people. Nevertheless, it should be noted that when the target of prejudice is represented by people categorized as Angolans, Mozambicans, or Cape-Verdians (people from the former Portuguese African colonies), and not by "Black" people, the expression of blatant prejudice rises, showing that the antiprejudice norm only positively affects the specific target "Black people" (Cabecinhas, 2002).

The European Social Survey (ESS-1/2002) measured explicit traditional racism using two items: "Thinking about people who have come to live in Portugal from another country and who are of a different race or ethnic group from most of Portuguese people - how much would you mind or not mind if someone like this...(a) was appointed as your boss?; (b) married a close relative of yours $(0=$ not mind at all; $10=$ mind a lot). An analysis of these ESS data showed that Portugal manifests a lower expression of explicit traditional racism when compared to the remaining 14 countries of the European Community (EC; before the admission of the new EC members), $F(1,29,692)=10.96, p<.001\left(M_{\text {Portugal }}=2.89, M_{\text {EUCountries }}=\right.$ 3.25).

Also based on this survey's data, we calculated an index of ethnic orientation toward immigrants by subtracting the degree of rejection of immigrants of a "different ethnic group" from the degree of rejection of immigrants of the same "ethnic group." We compared the obtained results from Portugal $(n=1,511)$ with those of France $(n=1,503)$, the United Kingdom $(n=2,052)$, and Germany $(n=2,919)$. In the four samples there is a greater acceptance of immigrants of the same ethnic group than of a different ethnic group; but the ethnic orientation in 
Portugal is, nevertheless, smaller than in the remaining countries, $F(3,16,323)=$ $47.13, p<.001\left(M_{\text {Portugal }}=.12, M_{\text {France }}=.18, M_{\text {Germany }}=.19, M_{U K}=.25\right.$, post hoc Duncan $p s<.001)$. Briefly, these results show that the antiprejudice norm is salient in Portugal, a result that might be attributed, at least partially, to the pervasiveness of the luso-tropicalist representation in the Portuguese society.

\section{Portuguese National Identity as a Predictor of Prejudice}

While the pervasiveness of the luso-tropicalist representation helps to explain the salience of the antiprejudice norm in Portuguese society, its pervasiveness may also explain the absence of a correlation between national identification and antiBlack prejudice in Portugal.

The data collected in five European countries reported in Pettigrew and Meertens' (1995) paper (see also Esses, Dovidio, Jackson, \& Armstrong, 2001) show that national identification and prejudice toward minorities are strongly and positively related. But this association may be moderated in the way people represent their nation and its history (Brewer \& Miller, 1996; Citrin, Wong, \& Duff, 2001; Kelman, 2001); by the representation of patriotism versus nationalism (Kosterman \& Feshbach, 1989; Mummendey, Klink, \& Brown, 2001; Staub, 1997); and by the representation of a nation as an unique entity, or as an aggregate of entities (for the Belgium case, see Billiet, Maddens, \& Beerten, 2003; for the Spanish case, see Ros, Huici, \& Gómez, 2000).

What can be said about the influence of luso-tropicalism regarding the association between the identification with the nation and the orientation toward prejudice? We propose that luso-tropicalism weakens the association between ingroup identification and orientation toward explicit discrimination of minorities. ${ }^{3}$

In 1997, Vala, Brito, and Lopes ran a survey study about racism in Portugal using a probability sample of White Portuguese respondents, aged 18-64 years, living in the Lisbon urban area $(N=600)$. Using a regression model that included traditional prejudice predictors (such as relative deprivation; see Pettigrew et al., 2008), Vala et al. (1999) showed that white racial identification predicts blatant prejudice, while the same is not true for identification with Portugal (Table 1). However, using a similar model of predictors, Pettigrew and Meertens (1995) found

\footnotetext{
${ }^{3}$ As Gilberto Freyre refers, "the idea that Portuguese are not xenophobic might be attributed to the fact that Portuguese law never prohibited the existence of ethnical minorities within its reign-for instance, Moorish and Jews - nor of their traditions, recognizing, on the contrary, their possibility of having their own laws" (p. 198). Moreover, in Freire's interpretation, which forgets, for instance, the expulsion of Jews in 1496, "besides" not being xenophobe, the Portuguese colonizer was a real cosmopolitan, "a cosmopolitanism favored mainly by the geographical position of the reign: a country largely maritime, varying in human contacts since remote times" (p. 198). Anyway, Freyre invites us to recognize that "only the latifundium slavery colonization would be capable of resisting the enormous obstacles that were raised to the civilization of Brazil by the Europeans" (p. 240). Gilberto Freyre bases his assumption on Portuguese intellectuals who in the 1930s were concerned with the definition of national identity.
} 
Table 1. Predictors of Blatant and Subtle Prejudice in Portugal (Stepwise Multiple Regression Analysis)

\begin{tabular}{|c|c|}
\hline Predictors & $\begin{array}{c}\text { Blatant Prejudice } \\
\text { Beta Values }\end{array}$ \\
\hline \multicolumn{2}{|l|}{ Sociodemographic variables } \\
\hline Age & $n s$ \\
\hline Socioprofessional group ${ }^{+}$ & $n s$ \\
\hline Educational level & $-.12^{* *}$ \\
\hline \multicolumn{2}{|c|}{ Intergroup/competition for resources variables } \\
\hline Perception of interdependence $^{+}$ & $.30^{*}$ \\
\hline Intergroup relative deprivation & $.15^{*}$ \\
\hline \multicolumn{2}{|c|}{ Intergroup identity/self-categorization variables } \\
\hline Racial identity & $.19^{*}$ \\
\hline National identity & $n s$ \\
\hline \multicolumn{2}{|c|}{ Psychological individual differences variables } \\
\hline Ethnocentrism & $n s$ \\
\hline Incongruence & $.11^{* *}$ \\
\hline \multicolumn{2}{|c|}{ Ideological individual differences variables } \\
\hline Moral conservatism & $.17^{*}$ \\
\hline Political conservatism $^{+}$ & $n s$ \\
\hline Political positioning (left-right) & $n s$ \\
\hline Social justice distributive norms ${ }^{+}$ & $n s$ \\
\hline \multicolumn{2}{|l|}{ Interpersonal (contact) variables } \\
\hline Black friend $^{+}$ & $-.11^{* *}$ \\
\hline 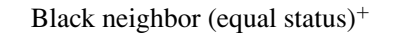 & $n s$ \\
\hline Adj. $R^{2}$ & .50 \\
\hline
\end{tabular}

${ }^{+}$Dummy variables; ${ }^{*} p<.001 ;{ }^{* *} p<.01$.

Note. This table was adapted from "Expressões dos racismos em Portugal" by J. Vala, R. Brito, and D. Lopes with kind permission of Imprensa de Ciências Sociais, Lisboa, Portugal.

significant effects of national identification on prejudice in different European countries.

These results were replicated using data from the ESS-2/2004. This survey includes questions concerning opposition to immigrants from poor, non-European countries and to those who are perceived to belong to other "races" or different "ethnic origins." The Portuguese version of this same survey $(N=2,052$; females $=58.4 \%$; mean age $=46.4$ ) also included a measure of national identification. National identification was measured using an adaptation of Aron, Aron, and Smollan's (1992) Inclusion of Other in the Self Scale, and of Tropp and Wright's (2001) Ingroup in the Self Scale. This allowed testing our hypothesis with a new dependent variable and a new set of predictors. The results reveal that identification with Portugal is not a significant predictor of opposition to immigration. Regrettably, in this study, as well as in the previous one, it was not possible to draw direct comparisons between the results obtained in Portugal and the results obtained in other countries.

This limitation was surmounted in yet another study (Vala, Lima, \& Lopes, 2004) comparing the predictive power of national identity in Portugal and in the remaining 14 European countries (before the admission of new members to the EU). Data from the 1999 European Values Study were used. The index of prejudice 
Table 2. Predictors of Perception of Threat in European Countries (Stepwise Multiple

Regression Analysis)

\begin{tabular}{|c|c|c|c|c|c|c|c|c|c|c|c|c|}
\hline \multirow[b]{3}{*}{ Predictors } & \multicolumn{6}{|c|}{8 European Countries ${ }^{a}$} & \multicolumn{6}{|c|}{ Portugal $^{\mathrm{b}}$} \\
\hline & \multicolumn{2}{|c|}{$\begin{array}{l}\text { Symbolic } \\
\text { Threat }\end{array}$} & \multicolumn{2}{|c|}{$\begin{array}{l}\text { Safety } \\
\text { Threat }\end{array}$} & \multicolumn{2}{|c|}{$\begin{array}{c}\text { Economical } \\
\text { Threat }\end{array}$} & \multicolumn{2}{|c|}{$\begin{array}{l}\text { Symbolic } \\
\text { Threat }\end{array}$} & \multicolumn{2}{|c|}{$\begin{array}{l}\text { Safety } \\
\text { Threat }\end{array}$} & \multicolumn{2}{|c|}{$\begin{array}{c}\text { Economical } \\
\text { Threat }\end{array}$} \\
\hline & Beta & $p$ & Beta & $p$ & Beta & $p$ & Beta & $p$ & Beta & $p$ & Beta & $p$ \\
\hline Education & -.210 & .000 & -.182 & .000 & -.345 & .000 & -.116 & .000 & -.132 & .000 & -.270 & .000 \\
\hline Age & .058 & .000 & .144 & .000 & .061 & .000 & .013 & .628 & .015 & .571 & -.102 & .001 \\
\hline N. identity & .096 & .000 & .102 & .000 & .104 & .000 & .014 & .608 & .009 & .728 & .033 & .201 \\
\hline Adj. $R^{2}$ & \multicolumn{2}{|c|}{.068} & \multicolumn{2}{|c|}{.083} & \multicolumn{2}{|c|}{.152} & \multicolumn{2}{|c|}{.013} & \multicolumn{2}{|c|}{.017} & \multicolumn{2}{|c|}{.051} \\
\hline
\end{tabular}

${ }^{\mathrm{a}} N=11,300 ;{ }^{\mathrm{b}} N=1,600$.

used in this study is quite broad. As shown by the authors, national identification predicts prejudice in European countries as a whole but not in Portugal.

This pattern of results was replicated using data from the International Social Survey Program 2003/2004 (databases available in April 2005: Ireland, United Kingdom, Portugal, Sweden, Finland, France, Germany, Denmark, and Spain). A summary of these results is presented in Table 2. Using the perception of threat associated to immigration as the dependent variable, the findings showed, once again, that national identity predicts perception of symbolic threat (cultural threat) and realistic threat (economical threat and threat to security) in the eight national samples that were analyzed. However, this same pattern of associations was not found in Portugal. Separate analyses were also conducted for each country. While controlling for age and educational level, national pride and perception of threat show a positive and significant correlation in Denmark $(\beta=.22, p<.001)$, Spain $(\beta=.23, p<.001)$, Finland $(\beta=.14, p<.001)$, France $(\beta=.13, p<.001)$, Germany $(\beta=.13, p<.001)$, and Sweden $(\beta=.14, p<.001)$. In the United Kingdom and in Ireland this result was not obtained.

In short, even though luso-tropicalism targets are essentially Black individuals, these new results show that luso-tropicalism effects can spread to a more general category of "immigrants," independently of their country of origin or the color of their skin.

In summary, and within the more general framework of the representation of the nation as a moderator of the relationship between national identification and prejudice, we propose that the representation of the Portuguese "national character" created by luso-tropicalism might explain the absence of a correlation between national identity and ethnic prejudice observed in different surveys. This hypothesis seems highly plausible, despite the fact that we do not possess direct measures of the moderating role of luso-tropicalism.

\section{Heteroethnicization, Luso-Tropicalism, and Prejudice}

Does luso-tropicalism also constitute a buffer for subtle forms of prejudice? Consider the covert negative evaluation of attributed cultural differences. In fact, 
luso-tropicalism, as a social representation, assumes that the Portuguese have a special tolerance toward traditions, customs, and values of populations with whom they had contact in the past, during the period of colonization, and in the present, with immigrants-specifically Black immigrants. ${ }^{4}$ Thus, contrary to the findings of the literature that hold that perceived cultural differences relate positively with prejudice toward out-groups (Leach, Peng, \& Volkens, 2000; Pettigrew \& Meertens, 1995; Rokeach, Smith, \& Evans, 1960; Sears \& Henry, 2003), according to luso-tropicalism, the Portuguese would not express the same negative attitudes. In order to analyze this new hypothesis, we will first present our prediction concerning the heteroethnicization process.

In the context of the construction of the representations of differences between human groups, we define heteroethnicization as the process through which a different and inferior culture is implicitly attributed to minority outgroups (Vala, Lopes, Lima, \& Brito, 2002). This process should be understood in the context of the transformation of the expression of racism in democratic societies. In fact, these societies abandoned the explanations based on racial differences and replaced them by cultural differences, meaning that cultural inferiorization substituted for racial inferiorization. However, we put forward the hypothesis that nowadays cultural inferiorization is also no longer socially acceptable.

In this vein, we propose that, today, the expression of cultural inferiority of the "other" is not voiced in an overt way, but rather in a covert way. This covert expression of cultural inferiority might nowadays be manifested through the accentuation of cultural differences between minority and majority groups, a process that hides an implicit negative evaluation of the minority cultures. We are not proposing that traditional racism has vanished. Neither do we hold that the relation between biological racism and discrimination is mediated by perceived differences as proposed, but not empirically demonstrated, by Leach et al. (2000). We argue that today's racism can be expressed in a way that is not perceived as antinormative, for example, through the attribution and implicit negative evaluation of cultural differences. This hypothesis received indirect support in Pettigrew and Meertens' (1995) study. In fact, the cultural differences subscale is part of their Subtle Racism Scale, which in turn correlates with the Blatant Racism Scale.

\section{Empirical Evidence with a Sample of "White" Portuguese Respondents}

Can it be that in Portuguese society, contrary to other European societies, people do not endorse covert inferiorization of immigrants' culture, or immigrants'

\footnotetext{
${ }^{4}$ As we already emphasized in the previous note, this idea is central in the representation of Portuguese colonization as described by Gilberto Freyre. According to this author. "[The Portuguese] was the European colonizer that came closer to the so-called inferior races. The less cruel in the relation with slaves (...), oriented to race crossing and to mestiçagem, a tendency that stems from the higher social plasticity found in Portuguese people than in other types of European colonizers" (p. 191).
} 
heteroethnicization? And is the process of heteroethnicization a functional equivalent of the process of heteroracialization? In order to answer these questions, we used a measure of overt racial inferiorization of Black people (items adapted from Pettigrew and Meertens' (1995) Intimacy Scale: "I would refuse to have sexual relationships with a Black person"; "I would mind if a Black person who had a similar economical background as me joined my close family by marriage"; "Black people come from less able races and this explains why they are not as well off as most Portuguese people"; "I would be bothered if a child of mine married a 'Black' person and that my grandchildren were "mestizos"'-_all response scales varying from strongly agree to strongly disagree). And we also used a measure of heteroethnicization that taps the perceived differences between White Portuguese and Black people in terms of family, religion, and sexual values (items adapted from Pettigrew and Meertens' (1995), subscale of accentuation of cultural differences: "How different or similar do you think Black people living here are to other Portuguese people like yourself. ..? (a) in the values that they teach to children; (b) in their religious beliefs and practices; (c) in their sexual values or sexual behaviors; (d) in their concern with their families' welfare; (e) in the education they give to children)." Note that the heteroethnicization measure does not involve an explicit evaluation of perceived differences or of the customs and values of the outgroup.

Using the data of Vala et al.'s (1999) correlational study presented above, we tested two models: a model that analyzes the nonassociation between the cultural differentiation (i.e., heteroethnicization) factor and the racial inferiorization (i.e., heteroracialization) factor, and another model that tests those two factors as being correlated. This last model corresponds to our hypothesis.

The fit indices obtained in the analyses show that the two correlated factors model fits the data better than the model that does not predict the association between the two factors. Indeed, the two factors correlated model presents better absolute and comparative fits, $\chi^{2}(26)=78.06, p<.001$, Goodness of Fit $(\mathrm{GFI})=$ .95 , Comparative Fit Index $(\mathrm{CFI})=.92$, root mean square error of approximation $($ RMSEA $)=.077$, when compared to the two uncorrelated factors model, $\chi^{2}(27)=$ 103.49, $p<.001$; GFI $=.94$; CFI $=.89$; RMSEA $=.091$. Moreover, when compared with the two uncorrelated factors model, the two correlated factors model shows a significant decrease in the chi-square model fit measure, $\Delta \chi^{2}(1)=$ $25.43, p<.001$. The confirmatory factor analysis supports our hypothesis of two distinct but correlated factors, suggesting that the accentuation of cultural differences is a process of inferiorization similar to that of the perception of racial differences.

However, to test our hypothesis fully, we must analyze the relations between the two-factors model and variables measuring discrimination and the negative evaluation of Black people (discrimination measure: participants were asked if it were a good idea or a bad idea to make the naturalization process easier for "Black" people. Participants were also asked how they would distribute 5,000 among the 


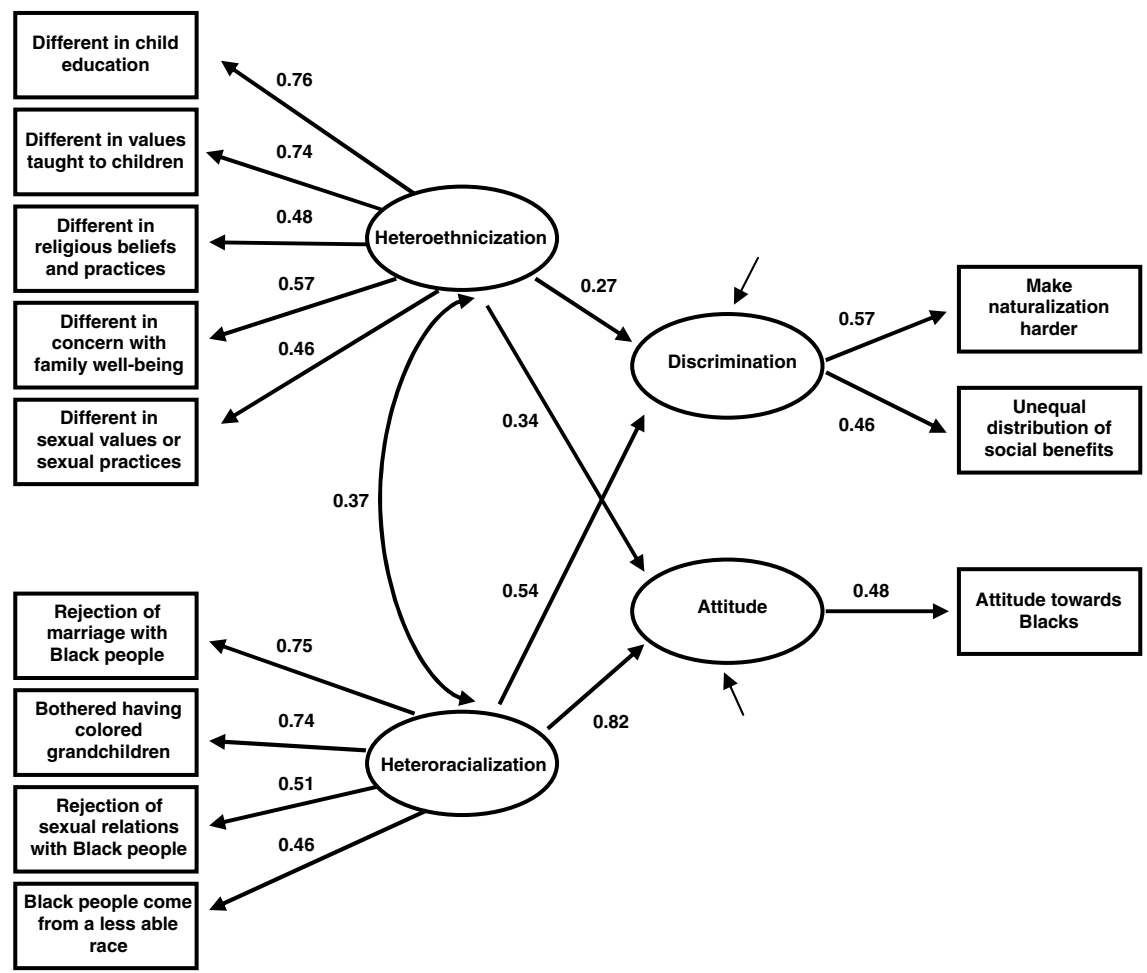

Note. Standardized solution; all coefficients significant at $p<.01 ; N=338 ; \chi^{2}(50)=148.12, p<$ $.001 ; \mathrm{GFI}=.94 ; \mathrm{CFI}=.90 ; \mathrm{RMSEA}=.076 ;$ Confidence Interval $(\mathrm{CI})=.062-.091$.

Fig. 1. Relation between heteroethnicization and heteroracialization, attitude toward "Black" people, and discrimination.

50 poorest "Black" people and by the 50 poorest "White" people of a poor Lisbon neighborhood-scale ranging from 0 to 5,000. And they were also asked to evaluate "Black" people using a scale that ranged from not at all favorable to very much favorable). The next structural equation model presented in Figure 1 tests the relationships between heteroethnicization and heteroracialization and attitudes and degree of discrimination of White Portuguese toward Blacks.

This model shows good absolute and relative fit indices. Both heteroethnicization and heteroracialization have a strong association with attitudes toward Blacks; thus, the greater the heteroethnicization or heteroracialization of Black Africans, the more negative the attitudes of White Portuguese toward them (respectively, $\gamma=.34$ and $\gamma=.82$ ). Also, these same two factors appear associated to a latent variable of discrimination. Note that the greater the heteroethnicization or heteroracialization, the more White Portuguese support the idea that the process of 
naturalization of Black immigrants should not be made easier, and the less they are willing to distribute social benefits to Blacks ( $\gamma=.27$ and $\gamma=.54$, respectively).

These results are supported by different theoretical perspectives (Brewer $\&$ Campbell, 1976; Rokeach, 1960), and they answer the questions we raised previously. That is, the perception of cultural differences hides a process of inferiorization, as it correlates with racialization, discrimination, and negative evaluations of Black people. Moreover, these results also show that the luso-tropicalist representation does not protect the White Portuguese against covert cultural inferiorization of out-group minorities. Indirect empirical evidence for our assumptions is also offered in the study of Pettigrew and Meertens (1995) carried out in four different Western European countries. Indeed, these authors also found a positive correlation between the attribution of cultural differences and blatant racism.

Nevertheless, these results are inconsistent with the theories that hold that it is not the difference between values and other group features that leads to discrimination, but, on the contrary, it is the similarity between groups that leads to differentiation and, in some situations, to discrimination (Tajfel \& Turner, 1979). Our findings also contradict the contentions of Coenders, Scheepers, Sniderman, and Verberk (2001). Partially reanalyzing the data used by Pettigrew and Meertens (1995, 2001), Coenders et al. (2001) maintained that general prejudice (explicit cultural inferiorization and explicit racial inferiorization) is independent of the "perception of cultural differences." In fact, Coenders, Lubbers, Scheepers, and Verkuyten (2008) assumed that the "perception of cultural difference items in Pettigrew and Meertens' scale (...) reflect not so much evaluative prejudices, but rather cognitive perceptions" (p. 295). They also argue that when, for instance, Dutch respondents say that a Turk is "very different" in religion, they are simply "acknowledging a social reality" (p. 298), and not necessarily expressing an evaluation. As plausible as the argument might seem at first, our results do not support it.

\section{Empirical Evidence with a Sample of Young Black Respondents}

Responding to this theoretical debate, we run another empirical test of our hypothesis, this time using a quota sample of Black respondents aged 15-29 years who live in the Lisbon urban area $(N=400$; females $=50 \%)$. The aim of this study was to analyze the psychological effects of Black people's perception of being seen as different, inasmuch as feeling discriminated. If the results of this study show that the perception of being seen as different is associated with discrimination, then we have new evidence from the targets themselves that the attribution of differences might not be a simple process of group description but a process of implicit group inferiorization.

In this study, we asked participants about the percentage of White Portuguese that would, in their opinion, agree with the items that, in the previous research, 
measured racialization and ethnicization. ${ }^{5}$ As in the preceding analyses with the White Portuguese sample, we again ran a confirmatory factor analysis and tested two factorial models: an uncorrelated two-factors model and a correlated twofactors model.

The two correlated factors model produces once more the best absolute and comparative fit indices, $\chi^{2}(26)=103.05, p<.001, \mathrm{GFI}=.94, \mathrm{CFI}=.93, \mathrm{RMSEA}$ $=.09$, over and above the uncorrelated two-factors model, $\chi^{2}(27)=154.75, p<$ $.001, \mathrm{GFI}=.91, \mathrm{CFI}=.88, \mathrm{RMSEA}=.11$. Moreover, when compared with the two uncorrelated factors model, the two correlated factors model presents a better fit, $\Delta \chi^{2}(1)=51.7, p<.001$.

A structural model testing the association between the perception by young Black people of heteroethnicization, perception of heteroracialization and procedural relative deprivation ${ }^{6}$ is presented in Figure 2.

As shown in Figure 2, the model reveals good fit indices. Heteroethnicization evidences a strong association with discrimination $(\gamma=.43)$, as is the case for heteroracialization $(\gamma=.72)$. This means that the more young Blacks perceive that they are ethnicized or racialized, the more they believe that they are treated unjustly by Portuguese institutions. Although the effects of perceived racialization are stronger than those of perceived ethnicization, the latter remain significant. The psychological meaning that we can derive from these results is that young Blacks perceive that White Portuguese perceive them to be culturally different, and that this metaperception corresponds to a sentiment of stigmatization.

\section{Discussion and Conclusions}

This article argues that the relations between receiving societies and immigrants is influenced by the representations that receiving societies build regarding their own history, namely their colonial past. Specifically, this article analyzed

\footnotetext{
${ }^{5}$ Specifically, the questions we asked participants concerning heteroracialization were: "In your opinion, what percentage of 'White' Portuguese answered 'yes' to the following questions:" "Yes, I would be bothered if a child of mine married a 'Black' person and my grandchildren were 'mestizos",; "Yes, I exclude having sexual relationships with a Black person"; "Yes, I consider that Black people belong to a less able race"; "Yes, I would mind if a Black person who had a similar economical background as me joined my close family by marriage." Concerning heteroethnicization, we asked for the percentage of "White" Portuguese that said that Black people were different in terms of (a) the values that they teach to children, (b) their religious beliefs and practices, (c) their sexual values or sexual behaviors, (d) the concern with their families' welfare, and (e) the education they give to children.

${ }^{6}$ The procedural relative deprivation (Tyler \& Lind, 2001) index was created through the calculation of a difference score of two items: "How do you evaluate the way 'Black' people are treated in Portugal by public services and by offices of central administration (Health services, Schools, Court Houses, Foreign offices, etc). "How do you evaluate the way Portuguese are treated in Portugal by the public services and by the offices of central administration (Health services, Schools, Court Houses, Foreign offices, etc)? Both items were measured in a 5-point scale $(1=$ they are not treated with consideration and respect, $5=$ they are treated with consideration and respect). The same analysis was repeated with other discrimination measures and we obtained similar results.
} 


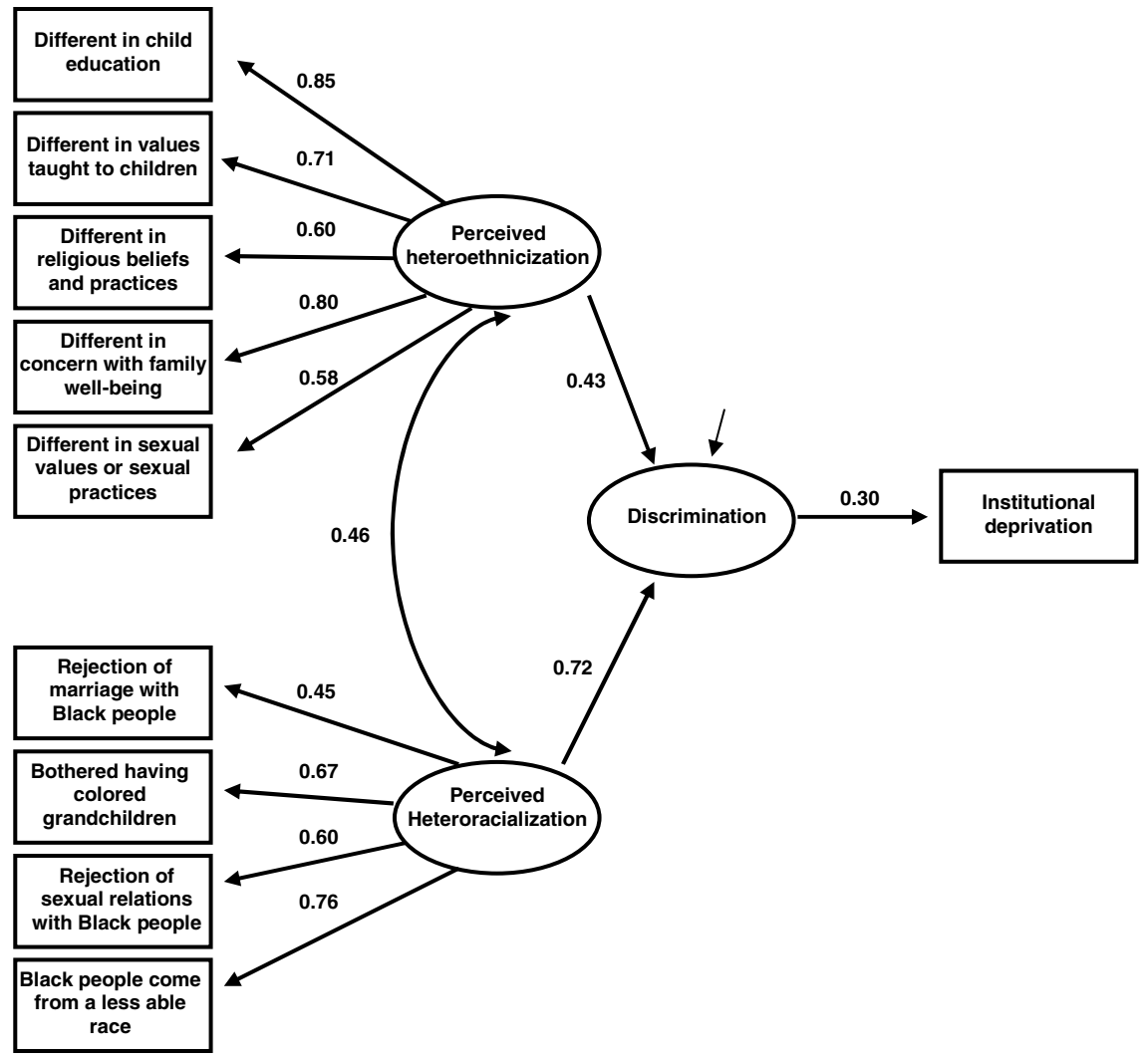

Note. Standardized solution. All coefficients significant at $p<.05 ; N=362 ; \chi^{2}(33)=123.17, p<$ $.001 ; \mathrm{GFI}=.93 ; \mathrm{CFI}=.92 ; \mathrm{RMSEA}=.087 \mathrm{CI}=.071-.104$.

Fig. 2. Relation between perceived heteroethnicization and perceived heteroracialization and discrimination.

in an exploratory way an association between the luso-tropicalist representation of the Portuguese colonial past and the type of social relations White Portuguese presently maintain with Black immigrants originating from the former Portuguese African colonies.

Data from different probability and quota samples were analyzed in order to illustrate the impact of luso-tropicalism on the salience of the antiprejudice norm, and on the absence of the usual association between national identification and prejudice in Portugal. Results suggest that the luso-tropicalist representation can contribute to the explanation of the prevalence of the antiprejudice norm, and that it can also suppress the impact of national identification on prejudice. This last finding is particularly relevant because a positive association between prejudice and national identity has been generally found in most European countries, as 
shown by Pettigrew and Meertens (1995, 2001), and by Jackson, Brown, Brown, and Marks (2001).

We propose that the representations on the relations between colonizers and colonized people can exert today an impact on the relations between host societies and immigrants. In the Portuguese case, the luso-tropicalist representation, stressing the "plasticity," "non-conflictual," "flexibility," and "cordiality" of the Portuguese "national character," might contribute to the weak association between national identity and prejudice in Portugal. This perspective extends previous empirical and theoretical arguments arguing that the association between national identity and prejudice can be moderated by lay people's representations of the nation (e.g., Billiet et al., 2003; Ros et al., 2000), by the meaning of nationalism (Kosterman \& Feshbach, 1989), and by the types of comparisons it raises (Mummendey et al., 2001).

A second dimension of the association between luso-tropicalist representation and integration of immigrants in the Portuguese society was also examined-the impact of luso-tropicalism on the attribution and covert evaluation of cultural differences. This problem was analyzed within the framework of the concept of heteroethnicization, a concept that refers to the attribution of cultural differences to minorities, resulting in their cultural inferiorization. In fact, our results reveal a correlation between heteroracialization and heteroethnicization, and these two forms of outgroup inferiorization are, in turn, correlated with negative attitudes toward Black African immigrants and intentions to discriminate them. Moreover, in the study of young Black Africans, we showed that the perception of being seen as different, or the perception of heteroethnicization, was correlated with the perception of being heteroracialized, and both perceptions were understood as forms of group stigmatization.

As a whole, results show that the luso-tropicalist representation about colonial relations may protect Portuguese against the public expression of overt prejudice, but does not protect them from new and hidden forms of prejudice, such as covert cultural inferiorization. However, the Portuguese myth about the uniqueness of Portuguese colonial relations was not measured directly in the studies we presented. Instead, we used a bottom-up strategy of argumentation associating the consistent differences of results found in Portugal and in other European countries, namely those relating national identity and prejudice, with the luso-tropicalist representation. Future research should directly measure the relationship between the luso-tropicalist representation and prejudice against immigrants.

\section{References}

Alexandre, V. (1999). O império e a ideia de raça (séculos XIX e XX) [The empire and the idea or race (XIX and XX centuries)]. In J. Vala (Ed.), Novos racismos: Perspectivas comparativas (pp. 133-144). Lisboa, Portugal: Celta Editora.

Aron, A., Aron, E. N., \& Smollan, D. (1992). Inclusion of other in the self scale and the structure of interpersonal closeness. Journal of Personality and Social Psychology, 63, 596-612. 
Billiet, J., Maddens, B., \& Beerten, R. (2003). National identity and attitude towards foreigners in a multinational state: A replication. Political Psychology, 24, 241-257.

Brewer, M. B., \& Campbell, D. T. (1976). Ethnocentrism and intergroup attitudes: East African evidence. New York: Halsted-Press.

Brewer, M. B., \& Miller, N. (1996). Intergroup relations. Buckingham, UK: Open University Press Books/Cole.

Cabecinhas, R. (2002). Racismo e etnicidade em Portugal: Uma análise psicossociológica da homogenei zação das minorias. [Racism and ethnicity in Portugal: A psycho-sociological analysis of minorities' homogenization]. Unpublished doctoral dissertation. Universidade do Minho, Braga, Portugal.

Castelo, C. (1999). O modo português de estar no mundo: O luso-tropicalismo e a ideologia colonial portuguesa-1933-1961 [The Portuguese way of relating to the world: Luso-tropicalism and the Portuguese colonial ideology]. Porto, Portugal: Afrontamento.

Citrin, J., Wong, C., \& Duff, B. (2001). The meaning of American national identity: Patterns of ethnic conflict and consensus. In R. D. Ashmore \& L. Jussim (Eds.), Social identity, intergroup conflict, and conflict reduction (pp. 71-100). London: Oxford University Press.

Coenders, M., Lubbers, L., Scheepers, P., \& Verkuyten, M. (2008). More than two decades of changing ethnic attitudes in the Netherlands. Journal of Social Issues, 64(2), 269-285.

Coenders, M., Scheepers, P., Sniderman, P., \& Verberk, G. (2001). Blatant and subtle prejudice: Different dimensions, different determinants, different consequences? Some comments on Pettigrew and Meertens. European Journal of Social Psychology, 31, 281-297.

De Las Casas, B. (1996). Brevíssima relação da destruição de África [A short report on the destruction of Africa]. Lisboa, Portugal: Antígona (Original work published 1552).

Esses, V. M., Dovidio, J. F., Jackson, L. M., \& Armstrong, T. L. (2001). The immigration dilemma: The role of perceived group competition, ethnic prejudice, and national identity. Journal of Social Issues, 57, 389-412.

Freyre, G. (1933). Casa grande e senzala [Masters and slaves]. Lisboa, Portugal: Livros do Brasil.

Jackson, J. S., Brown, K. T., Brown, T. N., \& Marks, B. (2001). Contemporary immigration policy orientation among dominant-group members in Western Europe. Journal of Social Issues, 57, $431-456$.

Kelman, H. C. (2001). The role of national identity in conflict resolution: Experiences from IsraeliPalestinian problem-solving workshops. In R. D. Ashmore, L. Jussim, \& D. Wilder (Eds.), Social identity, intergroup conflict, and conflict reduction (pp. 187-212). New York: Oxford University Press.

Kosterman, R., \& Feshbach, S. (1989). Toward a measure of patriotic and nationalistic attitudes. Political Psychology, 10, 257-274.

Leach, C. W., Peng, T. R., \& Volkens, J. (2000). Is racism dead? Comparing (expressive) means and (structural equation) models. British Journal of Social Psychology, 39, 449-465.

Moscovici, S. (1984). The phenomenon of social representations. In R. M. Farr \& S. Moscovici (Eds.), Social representations (pp. 3-69). Cambridge: Cambridge University Press.

Mummendey, A., Klink, A., \& Brown, R. (2001). Nationalism and patriotism: National identification and outgroup rejection. British Journal of Social Psychology, 40, 159-172.

Munanga, K. (1996). Mestiçagem e experiências interculturais no Brasil [Mestiçagem and intercultural experiences in Brasil]. In L. M. Schwartz \& L. V. S. Reis (Eds.), Negras imagens (pp. 179-193). São Paulo, Brazil: Editora da Universidade de S. Paulo.

Pettigrew, T. F., Christ, O., Wagner, U., Meertens, R. W., van Dick, R., \& Zick, A. (2008). Relative deprivation and intergroup prejudice. Journal of Social Issues, 64(2), 385-401.

Pettigrew, T. F., \& Meertens, R. W. (1995). Subtle and blatant prejudice in Western Europe. European Journal of Social Psychology, 25, 57-75.

Pettigrew, T. F., \& Meertens, R. W. (2001). In defense of the subtle prejudice concept: A retort. European Journal of Social Psychology, 31, 299-309.

Rokeach, M. (1960). The open and closed mind. New York: Basic Books.

Rokeach, M., Smith, P., \& Evans, R. (1960). Two kinds of prejudice or one? In M. Rokeach (Ed.), The open and closed mind (pp. 132-168). New York: Basic Books.

Ros, M., Huici, C., \& Gómez, A. (2000). Comparative identity, category salience and intergroup relations. In R. Brown \& D. Capozza (Eds.), Identity processes: Trends in theory and research (pp. 81-95). London: Sage. 
Schwarcz, L. M. (1996). Questão racial no Brasil [The racial issue in Brasil]. In L. M. Schwartz \& L. V. S. Reis (Eds.), Negras imagens (pp. 153-177). São Paulo, Brazil: Editora da Universidade de S. Paulo.

Sears, D. O., \& Henry, P. J. (2003). The origins of symbolic racism. Journal of Personality and Social Psychology, 85, 259-275.

Staub, E. (1997). Blind versus constructive patriotism: Moving from embededness in the group to critical loyalty and action. In D. Bar-Tal \& E. Staub (Eds.), Patriotism: In the lives of individual and nations (pp. 213-228). Chicago: Nelson-Hall.

Tajfel, H., \& Turner, J. C. (1979). An integrative theory of intergroup conflict. In S. Worchel \& W. G. Austin (Eds.), The social psychology of intergroup relations (pp. 33-47). Monterey, CA: Brooks/Cole.

Tyler, T. R., \& Lind, E. A. (2001). Understanding the nature of fraternalistic deprivation: Does groupbased deprivation involve fair outcome or fair treatment? In I. Walker \& H. J. Smith (Eds.), Relative deprivation: Specification, development, and integration (pp. 44-65). New York: Cambridge University Press.

Tropp, L. R., \& Wright, S. C. (2001). Ingroup identification as the inclusion of ingroup in the self. Personality and Social Psychology Bulletin, 27, 585-600.

Vala, J., Brito, R., \& Lopes, D. (1999). Expressões dos racismos em Portugal [Expressions of racisms in Portugal]. Lisboa, Portugal: Imprensa de Ciências Sociais.

Vala, J., Lima, M., \& Lopes, D. (2004). Social values, prejudice and solidarity in the European Union. In W. Arts \& L. Halman (Eds.), European values at the end of the millennium (pp. 139-161). Leiden, the Netherlands: Brill Academic Publishers.

Vala, J., Lopes, D., Lima, M., \& Brito, R. (2002). Cultural differences and hetero-ethnicization in Portugal: The perceptions of White and Black people. Portuguese Journal of Social Sciences, $1,111-128$.

Valentim, J. P. (2003). Identidade e lusofonia nas representações sociais de portugueses e de africanos [Identity and lusofonia in the social representations of Portuguese and Africans]. Unpublished doctoral dissertation. Universidade de Coimbra, Coimbra, Portugal.

JORGE VALA was Full Professor at the Department of Social and Organizational Psychology, ISCTE, Lisbon. Currently, he is a Researcher at the Instituto de Ciências Sociais, University of Lisbon. He has published papers on social representations and intergroup relations, namely in organizational and political domains and in the field of immigration issues. His current research focuses on racist beliefs, social norms, and social justice, and on processes of social validation of everyday knowledge.

DINIZ LOPES obtained his $\mathrm{PhD}$ from the Department of Social and Organizational Psychology, ISCTE, Lisbon, where he is an Assistant Professor. His research interests cover not only intergroup relations and conflicts but also the mechanisms used by people to validate their everyday knowledge and how these mechanisms interplay with other social psychological phenomena, such as social influence, information processing, and persuasion.

MARCUS LIMA studied at the Federal University of João Pessoa and obtained his $\mathrm{PhD}$ in Psychology at ISCTE, Lisbon. Currently, he is an Associate Professor at the Federal University of Sergipe, Brazil. He has authored papers on stereotypes, prejudice, and discrimination. He currently develops research on social norms and racist prejudice against Black people and Indians in Brazil. 